\title{
Constraining the timing of palaeosol development in Iranian arid environments using OSL dating
}

Rashidi, Zakieh; Sohbati, Reza; Karimi, Alireza; Farpoor, Mohammad Hadi; Khormali, Farhad; Thompson, Warren; Murray, Andrew Sean

Published in:
Quaternary Geochronology

Link to article, DOI:

10.1016/j.quageo.2018.04.006

Publication date:

2019

Document Version

Peer reviewed version

Link back to DTU Orbit

Citation (APA):

Rashidi, Z., Sohbati, R., Karimi, A., Farpoor, M. H., Khormali, F., Thompson, W., \& Murray, A. S. (2019).

Constraining the timing of palaeosol development in Iranian arid environments using OSL dating. Quaternary

Geochronology, 49, 92-100. https://doi.org/10.1016/j.quageo.2018.04.006

\section{General rights}

Copyright and moral rights for the publications made accessible in the public portal are retained by the authors and/or other copyright owners and it is a condition of accessing publications that users recognise and abide by the legal requirements associated with these rights.

- Users may download and print one copy of any publication from the public portal for the purpose of private study or research.

- You may not further distribute the material or use it for any profit-making activity or commercial gain

- You may freely distribute the URL identifying the publication in the public portal 


\section{Accepted Manuscript}

Constraining the timing of palaeosol development in Iranian arid environments using OSL dating

Zakieh Rashidi, Reza Sohbati, Alireza Karimi, Mohammad Hadi Farpoor, Farhad Khormali, Warren Thompson, Andrew Murray

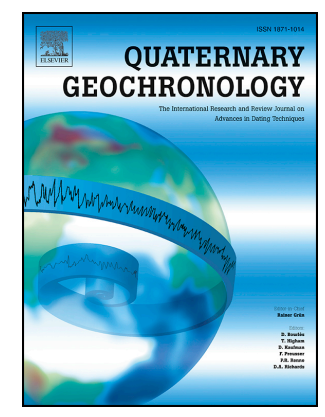

PII:

S1871-1014(17)30237-6

DOI:

10.1016/j.quageo.2018.04.006

Reference: QUAGEO 917

To appear in: Quaternary Geochronology

Received Date: 7 December 2017

Revised Date: 11 March 2018

Accepted Date: 11 April 2018

Please cite this article as: Rashidi, Z., Sohbati, R., Karimi, A., Farpoor, M.H., Khormali, F., Thompson, W., Murray, A., Constraining the timing of palaeosol development in Iranian arid environments using OSL dating, Quaternary Geochronology (2018), doi: 10.1016/j.quageo.2018.04.006.

This is a PDF file of an unedited manuscript that has been accepted for publication. As a service to our customers we are providing this early version of the manuscript. The manuscript will undergo copyediting, typesetting, and review of the resulting proof before it is published in its final form. Please note that during the production process errors may be discovered which could affect the content, and all legal disclaimers that apply to the journal pertain. 


\title{
Constraining the timing of palaeosol development in Iranian arid environments using OSL dating
}

Zakieh Rashidi $^{1-2}$, Reza Sohbati ${ }^{3}$, Alireza Karimi ${ }^{1 *}$, Mohammad Hadi Farpoor ${ }^{4}$, Farhad Khormali $^{5}$, Warren Thompson ${ }^{2}$, Andrew Murray $^{2}$

${ }^{1}$ Department of Soil Science, Faculty of Agriculture, Ferdowsi University of Mashhad, Mashhad, 91779-48978, Iran

${ }^{2}$ Nordic Laboratory for Luminescence Dating, Department of Geoscience, Aarhus University, DTU Risø Campus, DK-4000, Roskilde, Denmark

${ }^{3}$ Technical University of Denmark, Centre for Nuclear Technologies, DTU-Nutech, DTU Ris $\varnothing$ Campus, DK-4000, Roskilde, Denmark

\author{
${ }^{4}$ Department of Geological Sciences, Bahonar University of Kerman, Iran \\ ${ }^{5}$ Department of Soil Sciences, Gorgan University of Agricultural Sciences and Natural \\ Resources, Iran
}

*Corresponding author: karimi-a@um.ac.ir 


\section{$4 \quad$ Abstract}

5 The ages of palaeosols in arid environments in Iran are constrained using the optically

6 stimulated luminescence (OSL) signal from quartz. The luminescence properties of quartz

7 OSL and K-feldspar infrared stimulated luminescence (IRSL) at $50^{\circ} \mathrm{C}\left(\mathrm{IR}_{50}\right)$ and post-IR

8 IRSL at $290^{\circ} \mathrm{C}\left(\mathrm{pIRIR}_{290}\right)$ signals are compared to investigate the degree of bleaching of 9 quartz OSL in individual samples at the time of deposition. A comparison between the quartz 10 OSL and K-feldspar $\mathrm{IR}_{50}$ ages shows that 12 out of 15 samples were probably well-bleached 11 prior to deposition. The $17 \mathrm{OSL}$ ages constrain at least four broad phases of sediment deposition and soil formation on the central Iranian plateau: (i) prior to, and (ii) during, mid/late MIS 5 (at Isfahan and Lar), (iii) MIS 3 (at Bam, Mahan and probably Isfahan) and (iv) MIS 1 (at Rayen and Jiroft). In summary, there is no convincing evidence for palaeosol formation during MIS 4 and MIS 2; however pedogenesis does appear to have taken place during all other marine isotope stages over the last full glacial-interglacial cycle.

Keywords: Chronostratigraphy; Luminescence dating; Palaeoclimate; Bleaching; Marine isotope stage; Quartz OSL 


\section{Introduction}

Establishing a chronological framework is of crucial importance to palaeoclimate and landscape evolution studies. Without any knowledge of the timing of environmental change, understanding environmental history is not possible. Palaeosols are important archives for reconstruction of past climates and environments (e.g. Retallack, 2001); they are formed in response to environmental changes and can be used as records for understanding palaeoclamatic conditions. Palaeosols in various sediment sequences such as alluvial (e.g. Kemp et al., 2006), aeolian (e.g. Wang et al., 2016), marginal marine strata and even glacial deposits (e.g. Mahaney et al., 2013) are reliable indicators for stablishing a chronostratigraphic subdivision and correlation with marine isotope stages (MIS) and glacialinterglacial cycles (e.g. Gornitz, 2008). Palaeosols developed in alluvial deposits have the potential of providing information on episodes of landscape instability (sediment deposition), stability (soil development) and landscape evolution (Kraus, 1999).

The palaeoclimate records of Iran have been subject to several studies over the last decade (e.g. Karimi et al., 2009; Kehl, 2010; Khormali and Kehl, 2011). Quaternary events in Iranian plateau present important records of palaeoenvironmental changes in the arid environments of the Middle East. They can be seen as a valuable link for correlating Europe and Central Asia through the deserts of Saudi Arabia to the West and the deserts of Central Asia to the East; providing an understanding of palaeoenvironment and landscape evolution resulting in the genesis of the Old World Dry Belt (Kehl, 2010).

Most of the palaeoclimatic studies in Iran have been based on geomorphic and pedogenic evidence (e.g. Karimi et al., 2009; Khormali and Kehl., 2011; Farpoor et al., 2012; Ghafarpour et al., 2016). A few studies have applied absolute dating methods to studying palaeoenvironmental and landscape change in Iran (Kehl et al., 2005; Frechen et al., 2009; Karimi et al., 2011; Lauer et al., 2016; Büdel et al., 2017), but most focus on the loess- 
palaeosol sequences of Northern and Northeast of Iran (e.g. Frechen et al., 2009; Karimi et al., 2011; Lauer et al., 2016). Some of these studies suggest that well-developed palaeosols correlate with the last interglacial (MIS 5) or MIS 7 and older interglacials (Frechen et al., 2009; Lauer et al., 2016). Additionally, they suggest loess accumulation during last glacial period MIS 2 (Karimi et al., 2011).

In a recent study in northern Iran, stratigraphic results of Agh Band loess-palaeosol show poorly- as well as well-developed palaeosol horizons formed around $80 \mathrm{ka}$ and late MIS 7MIS 6 with increased humidity and landscape stability (Lauer et al., 2016). In southern Iran, apart from two studies (i.e. Kehl et al., 2005; Kehl et al., 2009), no information is available on the various phases of soil formation and sediment deposition. According to Kehl et al. (2005), based on the stratigraphy and different degrees of soil development, the welldeveloped $\mathrm{Bw}(\mathrm{t})$ and Btk horizons in the Persepolis basin, reflect probable soil-forming periods during MIS 5, while the upper loess deposits were likely formed under considerably cooler and drier climatic conditions during the LGM. The poorly-developed horizons indicate interstadial periods of MIS 3 and short phases of climate amelioration during the early Holocene.

It appears that there is little information available from the dry zones of Iranian plateau to allow the reconstruction of palaeoenvironment based on the timing of sediment depositionsoil formation sequences. This is partly due to the lack of reliable chronological control in the studies in this area. Alluvial fans and pediments are the most common landforms in the arid regions of Iran. The most developed soil horizon identified in these landforms is a Btk horizon in both buried and relict forms. Morphological, micromorphological and mineralogical characteristics of the palaeosols developed in these landforms have been previously described (Khademi and Mermurt, 1999; Khormali et al., 2003; Sanjari et al., 2011; Nejad Zamani., 2014). These studies investigated the pedogenesis of these arid-region 
soils using various techniques. Unfortunately, none of these studies provides quantitative

information on the timing of palaeosol development. Indeed, in the Middle East in general, the timing of sedimentation and pedogenesis in alluvial sediment is not well documented.

Given the similarity of palaeosols in the arid areas in Iran, an overall understanding of the timing of sedimentation and soil genesis episodes is very desirable. Here, we attempt to establish a first instrumental chronology for pedosedimentary events associated with previously identified palaeosols; these developed in alluvial fans and pediments in the arid areas of the Iranian plateau. Luminescence dating is used to set the first chronological constraints on the palaeosols, by determining the time at which the sediments, in which the palaeosols later formed, were deposited. Optically stimulated luminescence (OSL) is a wellestablished absolute dating method that determines the time elapsed since sediment grains were last exposed to daylight. In this method, quartz and feldspar grains act as natural dosimeters and can potentially yield ages of sediment deposition ranging from a few years to few hundred thousands of years. Many studies have made use of luminescence dating to establish a chronology for sedimentation and soil formation processes (e.g. Murray and Clemmensen, 2001; Leopold et al., 2011; Hal and Goble, 2015). In an attempt to establish a chronology for soil development, we apply luminescence dating to six different soil profiles in arid alluvial settings in Central Iranian plateau.

\section{Study area and sampling}

The Iranian Plateau is located in southwest Asia, between the Persian Gulf and the Oman Sea to the south and the Caspian Sea to the north (Darehshouri and Kasraian, 1998) (Fig. 1a). The study sites are located at six different geographical areas in the centre, east and southeast of the Iranian plateau (Fig. 1a). The present-day average annual precipitation and temperature range from 145 to $200 \mathrm{~mm}$ and from $14^{\circ} \mathrm{C}$ to $24.5^{\circ} \mathrm{C}$, respectively, thus the overall climate of the study area is considered arid. 
99 All our sections are located in alluvial and fluvial landforms and are physiographically similar (Table 1). Each section includes a representative pedon identified and logged in alluvial or fluvial deposits that originated from adjacent highlands. The location and environmental characteristics of sections are described in Table 1. These pedons consist of a sequence of palaeosol-sediment or a sequence of poorly- and well-developed palaeosols (Fig. 1b). The studied pedons and their sediment origins have long geological history, spanning from Miocene to present and Cretaceous to Pliocene, respectively. Because the most part of the Iranian plateau is covered by limestone formations, the parent material of most of the pedons studied here are calcareous; dominated by limestone and marl. The representative pedons were described and soil horizons identified according to the criteria of the Soil Survey Staff (2014).

In total, seventeen samples were collected for luminescence dating by hammering metal tubes well-developed palaeosols, (ii) two samples from less developed palaeosols, and (iii) three samples from sediment layers without or with very little pedogenic material (Fig. 1b). At each site (except for Isfahan where the ground surface was reworked by agricultural activity), an additional sample was collected by brushing the very top surface $(<2 \mathrm{~cm})$ of the ground into aluminium foil which was then wrapped and sealed in light-tight bags. Such modern analogues were taken to estimate the degree of bleaching (i.e. residual dose) in currentlyexposed samples. In addition to the luminescence samples, 250 grams of material from around each tube was collected for annual dose rate measurements.

\section{Sample preparation and analytical facilities}

121 Sediment was removed from sampling tubes under subdued orange light. Material from the exposed ends was saved for water content measurements and sediment from the middle (unexposed) part of the tubes was wet sieved to $125-250 \mu \mathrm{m}$. This fraction was then treated 
with $10 \% \mathrm{HCl}$ to remove carbonates. The presence of gypsum in some of the samples

125

126

127

presented a challenge in sample preparation; gypsum dissolves in water very slowly. To accelerate this dissolution, we treated the samples with a mixture of citric acid and propanol repeatedly until all or the majority of gypsum was removed. The samples were subsequently treated by $10 \% \mathrm{H}_{2} \mathrm{O}_{2}$ to remove any reactive organic material, followed by $10 \% \mathrm{HF}$ for 40 min. to remove any alpha-irradiated surface layer and weathering products and coatings, and $10 \% \mathrm{HCl}$ for $20 \mathrm{~min}$. to remove any fluoride precipitation. The K-rich feldspar fractions were separated by suspension in a water-based heavy liquid solution ( $\rho=2.58$ g.cm ${ }^{-3}$; Fastfloat). The denser (settled) quartz grains $\left(\rho>2.58{\mathrm{~g} . \mathrm{cm}^{-3}}^{-3}\right.$ were further treated with concentrated (40\%) $\mathrm{HF}$ for $60 \mathrm{~min}$. followed by $10 \% \mathrm{HCl}$ for $40 \mathrm{~min}$. .

All luminescence measurements were carried out using a Risø TL/OSL reader (model TL-DA 20), with blue light stimulation $\left(470 \mathrm{~nm}, \sim 80 \mathrm{~mW} . \mathrm{cm}^{-2}\right)$ and photon detection through a 7.5mm Hoya U-340 glass filter for quartz, and infrared stimulation $\left(875 \mathrm{~nm}, \sim 135 \mathrm{~mW} . \mathrm{cm}^{-2}\right)$ and photon detection through a Schott BG39/BG3 filter combination (2 and 3mm, respectively) for K-feldspar (Bøtter- Jensen et al., 2010). Beta irradiations used a ${ }^{90} \mathrm{Sr} /{ }^{90} \mathrm{Y}$ source mounted on the reader and calibrated for both discs and cups using 180-250 $\mu \mathrm{m}$ calibration quartz grains (Hansen et al., 2015). Grains were mounted as large (9 mm diameter for quartz) or medium ( $4 \mathrm{~mm}$ diameter for feldspar) aliquots in a monolayer on 9-mmdiameter stainless steel discs (quartz) or cups (feldspar) using silicone oil. The heating rate was $5{ }^{\circ} \mathrm{C} . \mathrm{s}^{-1}$ throughout. All thermal treatments and stimulations at temperatures higher than $200{ }^{\circ} \mathrm{C}$ were carried out in nitrogen atmosphere, and a pause of $5 \mathrm{~s}$ was inserted before stimulation to allow all grains to reach the measurement temperature. Five empty channels were inserted before and after the stimulation to monitor any isothermal TL signals.

\section{Dosimetry}


148 Radionuclide concentrations $\left({ }^{238} \mathrm{U},{ }^{232} \mathrm{Th}\right.$ and $\left.{ }^{40} \mathrm{~K}\right)$ were measured using high-resolution

149 gamma spectrometry. The additional sediment sample collected from around each metal tube was first dried at $50{ }^{\circ} \mathrm{C}$. A subsample of $\sim 250 \mathrm{~g}$ was pulverized and homogenized, and then heated to $450{ }^{\circ} \mathrm{C}$ for $24 \mathrm{~h}$ to remove any organic matter. The material was then cast in wax to prevent radon loss and to provide a reproducible counting geometry. Samples were stored for at least three weeks to allow ${ }^{222} \mathrm{Rn}$ to reach equilibrium with its parent ${ }^{226} \mathrm{Ra}$ before being measured on a high-purity Germanium detector for at least $24 \mathrm{~h}$. Details of the gamma spectrometry calibration are given in Murray et al. (1987). The internal beta dose rate from

${ }^{40} \mathrm{~K}$ to feldspar grains was calculated based on an assumed effective potassium content of $12.5 \pm 0.5 \%$ (Huntley and Baril, 1997), and the beta contribution from ${ }^{87} \mathrm{Rb}$ was calculated assuming a ${ }^{87} \mathrm{Rb}$ content of $400 \pm 100 \mathrm{ppm}$ (Huntley and Hancock, 2001). A small internal alpha contribution of $0.10 \pm 0.05 \mathrm{~Gy} \mathrm{ka}^{-1}$ from internal ${ }^{238} \mathrm{U}$ and ${ }^{232} \mathrm{Th}$ was also included in the dose rates, derived from ${ }^{238} \mathrm{U}$ and ${ }^{232} \mathrm{Th}$ concentration measurements by Mejdahl (1987). For quartz, an internal dose rate of $0.010 \pm 0.002 \mathrm{~Gy}_{\mathrm{ka}}{ }^{-1}$ was assumed (Vandenberghe et al., 2008). The radionuclide concentrations were converted to dose rate data using the conversion factors from Guerin et al. (2011). The cosmic-ray dose rates were calculated according to Prescott and Hutton (1994), assuming an uncertainty of 5\%. The long-term water content of each sample was estimated based on the field water content and saturation water content as well as the probable position of the water table during the burial time. All radionuclide concentrations, water contents and dose rates are summarized in Table 2.

\section{Luminescence characteristics and dose measurements}

\subsection{Quartz}

170 All the OSL measurements were performed at $125{ }^{\circ} \mathrm{C}$ for 40 s using a single-aliquot regenerative (SAR) protocol (Table S1; Murray and Wintle, 2000). A high-temperature blue light stimulation at $280{ }^{\circ} \mathrm{C}$ was applied at the end of each cycle to reduce recuperation (Table 
$\mathrm{S} 1$; Murray and Wintle, 2003). Values for $\mathrm{L}_{\mathrm{x}}$ and $\mathrm{T}_{\mathrm{x}}$ were derived from the initial $0.16 \mathrm{~s}$ of

174 the signal minus an immediate background derived from the following $0.16 \mathrm{~s}$. An early background subtraction was used to minimize the possible effect of the more difficult to bleach and more thermally unstable medium and slow components (Jain et al., 2003; Li and

177 Li, 2006; Cunningham and Wallinga, 2010).

178 For all the samples, the purity of quartz extracts was examined by measuring the OSL signal from three aliquots from each sample with and without prior IR stimulation at room temperature for $100 \mathrm{~s}$. The ratio of the two signals, the so-called OSL-IR depletion ratio, was then calculated for each aliquot (Duller, 2003). The resulting average OSL-IR depletion ratio was $0.90 \pm 0.03(\mathrm{n}=51)$, implying that any feldspar contamination in our quartz OSL signal is not significant. Quartz extracts from all the samples were sensitive and the OSL signal was dominated by the fast component (Fig. 2a, inset). Figure $2 \mathrm{a}$ shows a typical dose-response curve for sample 177118, fitted with a saturating exponential function; the sensitivitycorrected signals are reproducible (recycling ratio is close to unity), the dose-response curve passes through the origin (recuperation is small) and the $\mathrm{D}_{\mathrm{e}}$ for this aliquot is $\sim 111 \mathrm{~Gy}$.

Both natural and dose recovery preheat plateau tests were performed to determine the appropriate measurement conditions. The natural preheat-plateau test was carried out to investigate the dependence of equivalent dose $\left(D_{e}\right)$ on preheat temperature. Twenty-one aliquots of quartz from sample 177118 were sorted into groups of three. The $\mathrm{D}_{\mathrm{e}}$ was measured with different preheat temperatures for each group, in steps of $20^{\circ} \mathrm{C}$ ranging from $180^{\circ} \mathrm{C}$ to $300^{\circ} \mathrm{C}$ (held for $10 \mathrm{~s}$ ). The temperature of the cut heat was chosen to be $40{ }^{\circ} \mathrm{C}$ lower than that of the first preheat treatment. From Fig. $2 b$ it can be seen that there is no systematic dependence of $\mathrm{D}_{\mathrm{e}}$ on preheat temperature between 180 and $300{ }^{\circ} \mathrm{C}$. 
room temperature. A pause of $10000 \mathrm{~s}$ was used between the two stimulations to allow any charge trapped in shallow refuge traps (especially that associated with the $110{ }^{\circ} \mathrm{C}$ TL peak) to decay and subsequently partly refill the OSL trap before the second stimulation. The aliquots were then given a laboratory dose of $\sim 75 \mathrm{~Gy}$ and measured in a similar manner as in the natural preheat plateau test. Figure $2 \mathrm{c}$ illustrates the results of measured to given dose ratios at different preheat temperatures. As with the $\mathrm{D}_{\mathrm{e}}$ preheat plateau, no systematic dependence of dose recovery ratio on preheat temperature is observed. The average dose recovery ratio is $1.06 \pm 0.04(\mathrm{n}=21)$, showing that a known laboratory dose given to the sample before any thermal treatment can be measured accurately. Based on these results, we selected a preheat temperature of $240{ }^{\circ} \mathrm{C}$, and undertook a further dose recovery tests on all the samples at this temperature; the overall dose recovery ratio is $0.88 \pm 0.05(\mathrm{n}=51$; inset to Fig. $2 \mathrm{c})$. There is a large scatter in these data; the dose recovery ratios vary from 0.26 to 2.7 (inset to Fig. 2 c). Nevertheless, for all quartz OSL measurements described below a preheat/cutheat temperature of $240 / 200^{\circ} \mathrm{C}$ was used, although we further investigate the possible effect of this very variable dose recovery ratio on our quartz OSL ages in Section 6.

\subsection{K-rich feldspar}

A pIRIR 290 protocol was adopted to measure the K-feldspar fractions (Buylaert et al., 2012). The $\mathrm{D}_{\mathrm{e}}$ was measured using a SAR protocol with a preheat of $320{ }^{\circ} \mathrm{C}$ for $60 \mathrm{~s}$ after both regenerative and test doses. The first IR stimulation at $50{ }^{\circ} \mathrm{C}$ was followed by a second IR stimulation at $290{ }^{\circ} \mathrm{C}$. A high-temperature stimulation at $325{ }^{\circ} \mathrm{C}$ was also given at the end of each SAR cycle to minimise any build-up of charge giving rise to a recuperated signal. All IR stimulations were carried out for $100 \mathrm{~s}$ (Table S1). The pIRIR signals were derived from the first $1 \mathrm{~s}$ of the IR stimulation with a subtracted background based on the last $10 \mathrm{~s}$. Test dose values were chosen to be $\sim 25 \%$ of the pIRIR $290 \mathrm{D}_{\mathrm{e}}$ estimates for all samples. All dose response curves were fitted with a single saturating exponential function. 
223

224

225

226

227

228

229

230

231

232

233

234

235

236

237

238

239

240

241

242

243

244

\section{Quartz OSL ages and bleaching}

The quartz OSL ages of all the pedons are summarised in Fig.1b. The ages range from $5.2 \pm 0.6 \mathrm{ka}$ for the sediment in which a poorly-developed palaeosol $(\mathrm{Bk})$ has formed at the Jiroft section to $107 \pm 11 \mathrm{ka}$ for the sediment containing a well-developed Btky2 palaeosol at Isfahan section. The sediment ages at all sections are in stratigraphic order except at Isfahan where the age of the bottom Btky3 layer is younger than both the age of the immediately overlying Btky2 layer, and the unit above, containing Btky1. We do not consider the age of the bottom unit in the discussion below because it is younger than both the overlying samples and because the equivalent dose of the immediately overlying sample 177120 is 150 Gy (i.e. approaching saturation). It is well-known that quartz close to saturation tends to underestimate age (Chapot et al., 2012) and so it is not surprising that the age of the bottom sample is underestimated.

In the luminescence dating of samples from alluvial settings, one must always consider the possibility of incomplete resetting or bleaching of the signal before final deposition. The bleaching rate may be a function of several parameters such as water depth, sediment load, turbulence, light spectrum, grain size, and transport distance (e.g. Jain et al., 2004). To investigate the likely importance of incomplete bleaching, we use two approaches: i) we determine the residual dose in modern analogues, and ii) look at the relative doses recorded by two signals that bleach at different rates.

\subsection{Modern analogue}

One way to evaluate the significance of incomplete bleaching is to estimate the residual doses in currently-exposed deposits at the sampling site (e.g. Murray and Olley, 2002; Jain et al., 2004; Porat et al., 2010). Such modern analogues can provide useful information on the likely degree of bleaching in the fossil samples prior to deposition. Eighteen aliquots of quartz and twelve aliquots of K-feldspar were measured on material extracted from samples of 
identifiably modern sediment from 5 sites. Table 3 summarizes the quartz OSL and K-

feldspar $I_{50}$ and $\mathrm{pIRIR}_{290} \mathrm{D}_{\mathrm{e}}$ values of modern analogues from these sites. No representative

by agricultural activity. The quartz OSL residual doses range from $\sim 0.1 \mathrm{~Gy}$ (at Bam, Lar and

Mahan) to $\sim 1.6$ Gy (at Rayen). The largest $\mathrm{IR}_{50}$ and $\mathrm{pIRIR}_{290}$ doses are $\sim 2 \mathrm{~Gy}$ (at Mahan) and

5 Gy (at Rayen), respectively. All these doses are small compared to the equivalent doses

measured in the fossil samples from the corresponding site, suggesting that the fossil samples were likely to have been sufficiently bleached at the time of deposition.

\subsection{K-feldspar versus quartz}

Several studies have shown that the quartz OSL signal resets more rapidly than feldspar $\mathrm{IR}_{50}$ signal (e.g. Godfrey-Smith et al., 1988) and that the $\mathrm{IR}_{50}$ signal, in turn, bleaches more quickly than the pIRIR 290 signal (e.g. Murray et al., 2012). Unfortunately sufficient feldspar was not available from some samples, but Fig. 3a summarises the dose measurement made on the 15 samples for which sufficient material could be extracted (all sites). This plot of the $\mathrm{IR}_{50}$ versus pIRIR 290 equivalent doses shows that most data points are consistent with a straight line (Fig. 3a) of slope $0.47 \pm 0.02$. Given the heterogeneous nature of the bleaching process in space and time, the relatively constant relationship over a wide dose range implies that the feldspar signals in most of our samples are likely to have been well-bleached prior to deposition (e.g. Sohbati et al., 2016).

Based on the differential bleaching of quartz OSL and K-feldspar IRSL signals, Murray et al. (2012) proposed an approach to identifying well-bleached quartz by comparing quartz OSL with feldspar $\mathrm{IR}_{50}$ and pIRIR $_{290}$ ages. Following a similar approach, a comparison between the quartz OSL and the K-feldspar $\mathrm{IR}_{50}$ ages shows that, except for three samples (at Jiroft profile), the $\mathrm{IR}_{50}$ ages are comparable to or younger than the corresponding quartz ages (Fig. 
of fading expected for the $\mathrm{IR}_{50}$ signal, and suggesting that the quartz OSL signal in these samples is likely to have been well-bleached prior to deposition (all these samples are identified as 'probably well-bleached' in Table 2). The $\mathrm{IR}_{50}$ signal from the three samples from the Jiroft profile has apparently not been as well-bleached as those from the other profiles, and thus we do not know if the quartz signal in these samples was sufficiently reset. We also compared the quartz OSL ages with the pIRIR 290 ages. Figure $3 \mathrm{c}$ shows that the pIRIR $_{290}$ ages for 6 of the samples are consistent with the corresponding quartz OSL ages (identified as 'well-bleached' in Table 2); the remaining (including the 3 from the Jiroft profile) overestimate. This implies that despite the negligible pIRIR 290 residual doses in the modern analogues and the correlation between the $\mathrm{IR}_{50}$ and $\mathrm{pIRIR}_{290}$ over a wide dose range (Fig. 3a), the pIRIR 290 signal in some of our samples may not have been sufficiently bleached prior to deposition.

\subsection{Does quartz dose recovery affect the OSL ages}

In order to see whether the apparent difficulty in recovering a known dose for some aliquots (inset to Fig. 2c) is systematically affecting the measurement of dose in quartz, we compare the OSL to $\mathrm{IR}_{50}$ age ratio with the quartz OSL dose recovery ratio for all the samples. Figure $3 \mathrm{~d}$ shows that there is no correlation between the two ratios. Thus, the unsatisfactory dose recovery ratios observed for some of the samples does not seem to lead to a detectable systematic underestimation of the quartz age, as might otherwise have been expected. Since our quartz OSL ages do not seem to be affected either by poor dose recovery or by incomplete bleaching (with the possible exception of the Jiroft profile) the quartz ages are used in the geological interpretation of the next section.

\section{Discussion}

The Jirof section provides three OSL ages of between 5.2 \pm 0.6 and $15 \pm 2 \mathrm{ka}$. These OSL age estimates indicate the time of sediment deposition and so suggest that soil development 
started after $15 \mathrm{ka}$ ago, and was ongoing until at least the middle of the Holocene (although the youngest unit has only a poorly-developed soil). However, none of these 3 samples are identified as well- or probably-well bleached by comparison between the quartz OSL age and the feldspar ages, and so the calculated ages may be overestimates (marked with a (?) in Table 2).

The two samples from Rayen section give OSL age estimates of $5.5 \pm 0.5$ ka for a sediment with no significant soil development $60 \mathrm{~cm}$ below the surface, and $26 \pm 3 \mathrm{ka}$ for the most developed Btk horizon at $115 \mathrm{~cm}$; the 2 OSL ages are identified in Table 2 as well bleached and probably well bleached, respectively. It appears that alluvial deposition of this pedon took place before or around the LGM, and that soil formation took place later, resulting in a well-developed Btk horizon in depth of $115 \mathrm{~cm}$. Further alluvial sediments were deposited at $5.5 \pm 0.5 \mathrm{ka}$ (MIS 1), and no significant soil development took place in this unit, constraining the period of soil development in the underlying unit to between $26 \pm 3$ and $5.5 \pm 0.5 \mathrm{ka}$. The sharp transition between the lower well-developed soil horizon and the upper underdeveloped deposits suggests a chronological discontinuity in this pedon, for instance arising from an erosion event.

Finally, the uppermost unit at Mahan contains a well-developed Bt palaeosol in a sediment with a deposition age of $18.5 \pm 1.5 \mathrm{ka}$, and identified in Table 2 as well bleached. Although less well-constrained than at Jiroft and Rayen, this palaeosol may also have developed during the Holocene.

These results suggest that 5 units ( 3 at Jiroft, 1 at Rayen and 1 at Mahan) probably all developed soils to various degrees during the Holocene. The presence of a $5.5 \pm 0.5 \mathrm{ka}$ sediment cap at Rayen and only a weakly-developed soil in the youngest unit at Jiroft probably constrains the active soil development period to the early/mid Holocene. 
The stratigraphy and soil horizons recorded in the Bam pedon appear similar to those in the Rayen pedon, but deposition occurred much earlier, at $61 \pm 5 \mathrm{ka}$ (MIS 4), indicating soil formation probably after MIS 4. The age of the sample taken from upper coarse-grained deposits is $9.1 \pm 0.9 \mathrm{ka}$, substantially younger than the underlying sediment; this constrains the formation of this soil most likely to MIS 3, although soil formation in MIS 2 cannot be ruled out purely on stratigraphic grounds. The time gap between the two horizons may indicate an erosional event, possibly during MIS 2. One of the two samples appears to have been well reset, and the other probably well reset (Table 2).

The palaeosol-sediment sequence at Mahan gives stratigraphically consistent OSL age estimates ranging from $18.5 \pm 1.5$ to $65 \pm 4 \mathrm{ka}$ and all are identified as well or probably wellbleached (Table 2). The sediment sequence began to be deposited in MIS 4 (65 $\pm 4 \mathrm{ka})$ but soil development did not take place until after $54 \pm 4 \mathrm{ka}$, when a well-developed palaeosol (Btk 45$70 \mathrm{~cm}$ ) began to form. The upper unit was deposited at $18 \pm 1.1 \mathrm{ka}$ during MIS 2, and so the underlying soil probably developed during MIS 3.

The Isfahan section consists of a multiple pedocomplex. The OSL age estimates range from $40 \pm 8$ for a sample from the upper horizon at $50 \mathrm{~cm}$ below the surface to $107 \pm 11 \mathrm{ka}$ for the sedimentary unit at $140 \mathrm{~cm}$ (ignoring the unit below this for the reasons discussed above). All of the samples are judged to have been well-bleached or probably-well bleached before deposition (Table 2). The sediment sequence began to be deposited at $107 \pm 11 \mathrm{ka}$ or earlier and soil formation occurred later, but before $73 \pm 6 \mathrm{ka}$, when more sediment was deposited covering the palaeosol. Further pedogenesis occurred after this time, but before $40 \pm 8 \mathrm{ka}$, when more sediment was deposited. One final period of soil development is recorded at the top of this section, occurring after $40 \pm 8 \mathrm{ka}$. This palaeosol presumably developed at the same time as that found in the middle unit at Mahan (deposition at $54 \pm 4 \mathrm{ka}$ ), and possibly the bottom unit at Bam (deposition at $61 \pm 5 \mathrm{ka}$ ). Thus, it appears we have 4 periods of soil 
development represented at Isfahan, the first (bottom unit) of unknown age but before MIS

5d, one during mid/late MIS 5, one between MIS 5 and mid MIS 3, and the top palaeosol during late MIS 3.

The Lar section is similar to that at Isfahan. The earliest sediment deposition occurs at $102 \pm 10 \mathrm{ka}$. This unit is covered by one deposited at $73 \pm 12 \mathrm{ka}$, which is in turn covered by one from $43 \pm 5 \mathrm{ka}$. Unfortunately, feldspar was unavailable for these samples, and so we are unable to comment on the degree of bleaching prior to deposition. Each sedimentary unit contains a well-developed palaeosol, and thus, as with Isfahan, there are soil formation periods during mid/late MIS 5, one between MIS 5 and mid MIS 3, and one after mid MIS 3. In summary, we have firm evidence for soil formation before MIS 5d, during mid/late MIS 5, between MIS 5 and mid MIS 3, but probably in early MIS 3 (because of the constraining $54 \pm 4 \mathrm{ka}$ age at Mahan), during late MIS 3, and in the early to mid MIS 1.

\section{Conclusion}

For the first time, a chronology has been developed for the sediments hosting several soil profiles in the central Iranian plateau. Our OSL ages indicate the time at which the sediment was deposited; soil formation took place later. The 17 OSL ages constrain at least four broad phases of sediment deposition and soil formation on the central Iranian plateau: (i) prior to, and (ii) during, mid/late MIS 5 (at Isfahan and Lar), (iii) MIS 3 (at Bam, Mahan and probably Isfahan), and (iv) MIS 1 (at Rayen and Jiroft). It appears that, over the last full glacialinterglacial cycle, there is no convincing evidence for palaeosol formation during MIS 4 and MIS 2.

\section{Acknowledgements}

ZR would like to thank Aarhus University and the Ministry of Science, Research and Technology of Islamic Republic of Iran for financial support during her visit to Denmark. 


\section{References}

373 Bøtter-Jensen, L., Thomsen, K., Jain, M. 2010. Review of optically stimulated luminescence (OSL) instrumental developments for retrospective dosimetry. Radiation Measurements 45, 253-257.

Büdel, C., Padashi, S.M., Hoelzmann, P., Fuchs, M., Baumhauer, R., 2017. The correlation of North-Iranian Late Pleistocene and Holocene playa sediments to basin geomorphology. Zeitschrift für Geomorphologie 61, 77-99.

Buylaert, J.P., Jain, M., Murray, A.S., Thomsen, K.J., Thiel, C., Sohbati, R. 2012. A robust feldspar luminescence dating method for Middle and Late Pleistocene sediments. Boreas 41, 435-451.

Chapot, M.S., Roberts, H.M., Duller, G.A.T. and Lai, Z.P., 2012. A comparison of naturaland laboratory-generated dose response curves for quartz optically stimulated luminescence signals from Chinese Loess. Radiation Measurements, 47(11-12), 10451052.

Cunningham A.C., Wallinga, J. 2010. Selection of integration time intervals for quartz OSL decay curves. Quaternary Geochronology 5, 657-666.

Darehshouri, B. and Kasraian, N. 1998. Nature of Iran, Rozane-kar Press, p10.

Duller, G.A.T. 2003. Distinguishing quartz and feldspar in single grain luminescence measurements. Radiation Measurements 37, 161-165.

Farpoor, M.H., Neyestani, M., Eghbal, M.K., Esfandiarpour Borujeni, I. 2012. Soil geomorphology relationships in Sirjan playa, south central Iran. Geomorphology 138, 223-230.

Frechen, M., Kehl, M., Rolf, C., Sarvati, R., Skowronek, A. 2009. Loess chronology of the Caspian Lowland in northern Iran. Quaternary International 128, 220-233. 
396

397

398

399

400

401

402

403

404

405

406

407

408

409

410

411

412

413

414

415

416

417

418

419

420

Ghafarpour, A., Khormali, F., Balsam, W., Karimi, A., Ayoubi, S. 2016. Climatic interpretation of loess-paleosol sequences at Mobarakabad and Aghband, Northern Iran. Quaternary Research 86, 95-109.

Godfrey-Smith, D.L., Huntley, D.J., Chen, W.H. 1988. Optically dating studies of quartz and feldspar sediment extracts. Quaternary Science Reviews 7, 373-380.

Gornitz, V. 2008. Encyclopedia of Paleoclimatology and Ancient Environments, New York, Springer, Encyclopedia of Earth Sciences Series, 1049 p.

Guerin, G., Mercier. N., Adamiec, G. 2011. Dose-rate conversion factors: update. Ancient TL $29,5-8$

Hall, S. A. and Goble, R. J. 2015. OSL age and stratigraphy of the Strauss sand sheet in New Mexico, USA. Geomorphology 241, 42-54.

Hansen, V., Murray A.S., Buylaert J.P., Yeo, E., Thomsen, K. 2015. A new irradiated quartz for beta source calibration. Radiation Measurements 81: 123-127.

Huntley, D. and Baril, M. 1997. The K content of the K-feldspars being measured in optical dating or in thermoluminescence dating. Ancient TL 15, 11-13.

Huntley, D., Hancock, R. 2001. The Rb contents of the K-feldspar grains being measured in optical dating. Ancient TL 19, 43-46.

Jain, M., Murray, A. S., Bøtter-Jensen, L. 2003. Characterisation of bluelight stimulated luminescence components in different quartz samples: implications for dose measurement. Radiation Measurements 37, 441-449.

Jain, M., Murray, A.S., Bøtter-Jensen, L. 2004. Optically stimulated luminescence dating: how significant is incomplete light exposure in fluvial environments? Quaternaire 15, $143-157$.

Karimi, A., Frechen, M., Khademi, H., Kehl, M., Jalalian, A. 2011. Chronostratigraphy of loess deposits in northeast Iran. Quaternary International 234, 124-132. 
Karimi, A., Khademi, H., Kehl, M., Jalalian, A. 2009. Distribution, lithology and provenance of peridesert loess deposits in northeastern Iran. Geoderma 148, 241-250.

Kehl, M. 2010. Quaternary loesses, loess-like sediments, soils and climate change in Iran. Relief Boden Paläoklima, Band 24, 209 p.

Kehl, M., Frechen, M., Skowronek, A. 2009. Nature and age of Late Quaternary basin fill deposits in the Basin of Persepolis/Southern Iran. Quaternary International 196, 57-70.

Kehl, M., Frechen, M., Skowronek, A., 2005. Paleosols derived from loess and loess-like sediments in the Basin of Persepolis, Southern Iran. Quaternary International 140/141, 135-149.

Kemp, R. A., Zárate, M., Toms, P., King, M., Sanabria, J., Arguello, G. 2006. Late Quaternary paleosols, stratigraphy and landscape evolution in the Northern Pampa, Argentina. Quaternary Research 66, 119-132.

Khademi, H., Mermut, A.R. 1999. Submicroscopy and stable isotope geochemistry of carbonate and associated palygorskite in Iranian Aridisols. European Journal of Soil Science 50, 207-216.

Khormali, F., Abtahi, A., Mahmoodi, S., Stoops, G. 2003. Argillic horizon development in calcareous soils of arid and semiarid regions of southern Iran. Catena 53, 273-301.

Khormali, F., Kehl, M. 2011. Micromorphology and development of loess-derived surface and buried soils along a precipitation gradient in Northern Iran. Quaternary International 234, 109-123.

Kraus, M.J. 1999. Paleosols in clastic sedimentary rocks: their geologic applications. Earth Science Reviews 47, 41-70.

Lauer, T., Vlaminck, s., Frechen, M., Rolf, C., Kehl, M., Sharifi, J., Lehndorff, E., Khormali, F. 2016. The Agh Band loess-palaeosol sequence e A terrestrial archive for climatic 
shifts during the last and penultimate glacialeinterglacial cycles in a semiarid region in northern Iran. Quaternary International 429(B), 13-30.

447

Leopold, M., Völkel, J., Dethier, D., Huber, J., Steffens, M. 2011. Characteristics of a paleosol and its implication for the Critical Zone development, Rocky Mountain Front Range of Colorado, USA . Applied Geochemistry 26, S72-S75.

Li, B., Li, S. 2006. Comparison of estimates using the fast component and the medium component of quartz OSL. Radiation Measurements 41, 125-136.

Mahaney, W.C., Barendregt, R. W., Hamilton, T. S., Hancock, R. G. V., Tessler, D., Costa, P. J.M. 2013. Stratigraphy of the Gorges moraine system, Mount Kenya: palaeosol and palaeoclimate record. Journal of the Geological Society, London 170, 497-511.

Mejdahl, V. 1987. Internal radioactivity in quartz and feldspar grains. Ancient TL 5, 10-17.

Murray, A.S. and Wintle, A.G. 2000. Luminescence dating of quartz using an improved single-aliquot regenerative-dose protocol. Radiation Measurements 32, 57-73.

Murray, A.S. and Wintle, A.G. 2003. The single aliquot regenerative dose protocol: potential for improvements in reliability. Radiation Measurements 37, 377-381.

Murray, A.S., Clemmensen, L.B. 2001. Luminescence dating of Holocene aeolian sand movement, Thy, Denmark. Quaternary Science Reviews 20, 751-754.

Murray, A.S., Marten, R., Johnston, A., Martin, P. 1987. Analysis for naturally occurring radionuclides at environmental concentrations by gamma spectrometry. Journal of Radioanalytical and Nuclear Chemistry 115, 263-288.

Murray, A.S., Olley, J.M. 2002. Precision and accuracy in the optically stimulated luminescence dating of sedimentary quartz. Geochronometria 21, 1-16.

Murray, A.S., Thomsen, K.J., Masuda, N., Buylaert, J.P., Jain, M. 2012. Identifying wellbleached quartz using the different bleaching rates of quartz and feldspar luminescence signals. Radiation Measurements 47, 688-695. 
Nejadzamani, L., 2014. Soil-geomorphology relationships in Rayen, Kerman. Master thesis of Bahonar University of Kerman (in Persian).

Porat, N., Amit, R., Enzel, Y., Zilberman, E., Avni, Y., Ginat, H., Gluck, D. 2010. Abandonment ages of alluvial landforms in the hyperarid Negev determined by luminescence dating. Journal of Arid Environments 74, 861-869.

Prescott, J. Hutton, J. 1994. Cosmic ray contributions to dose rates for luminescence and ESR dating: large depths and long-term time variations. Radiation Measurements 23, 497500.

Retallack, G.J., 2001. Soils of the Past. An Introduction to Paleopedology. Blackwell.

Sanjari, S,. Farpoor, M.H., Eghbal, M.K., Esfandiarpour Borujeni, I. 2011. Genesis, micromorphology and clay mineralogy of soils located on different geomorphic surfaces in Jiroft area. Journal of Water and soil 20, 411-428 (in Persian).

Sohbati, R., Borella, J., Murray, A.S., Quigley, M., Buylaert, J.P. 2016. Optical dating of loessic hillslope sediments constrains timing of prehistoric rockfalls, Christchurch, New Zealand. Journal of Quaternary Science 31, 678-690.

Soil Survey Staff, 2014. Keys to Soil Taxonomy, 14th edition. U.S. Department of Agriculture, Natural Resources Conservation Service.

Vandenberghe D, De Corte F, Buylaert J.P., Kucera, J., Van den hautea, P. 2008. On the internal radioactivity in quartz. Radiation Measurements 43, 771-775.

Wang, X., Wei, H., Taheri, M., Khormali, F., Danukalova, G., Chen, F. 2016. Early Pleistocene climate in western arid central Asia inferred from loess-palaeosol sequences. Scientific Reports 6, Article number: 20560. 


\section{Figure captions}

501

502

Figure 1) (a) Map of the Middle East and Iran, showing the location of six sampling sites in the (semi-)arid zones of Iranian plateau. (b) Stratigraphy of palaeosol units and location of the OSL samples. The dashed lines indicate possible chronological correlations, not coeval soil development. There are marked discontinuities in all profiles. These may be erosional.

506

507

Figure 2) Summary of luminescence characteristics of quartz OSL signal. (a) Typical doseresponse and stimulation (inset) curves, (b) and (c) natural and dose recovery preheat plateau tests for a sample from Mahan (171118). Each data point represents the average of three aliquots. The error bars show one standard error. Inset to (c) shows the summary of dose recovery test for all the samples in this study.

512

513 Figure 3) (a) Sample-averaged K-feldspar equivalent doses. Error bars represent one 514 standard error, (b) quartz OSL and K-feldspar IR $_{50}$ ages, (c) quartz OSL and K-feldspar pIRIR 290 ages, (d) quartz OSL to K-feldspar IR $_{50}$ age ratio plotted against quartz dose recovery ratio. 


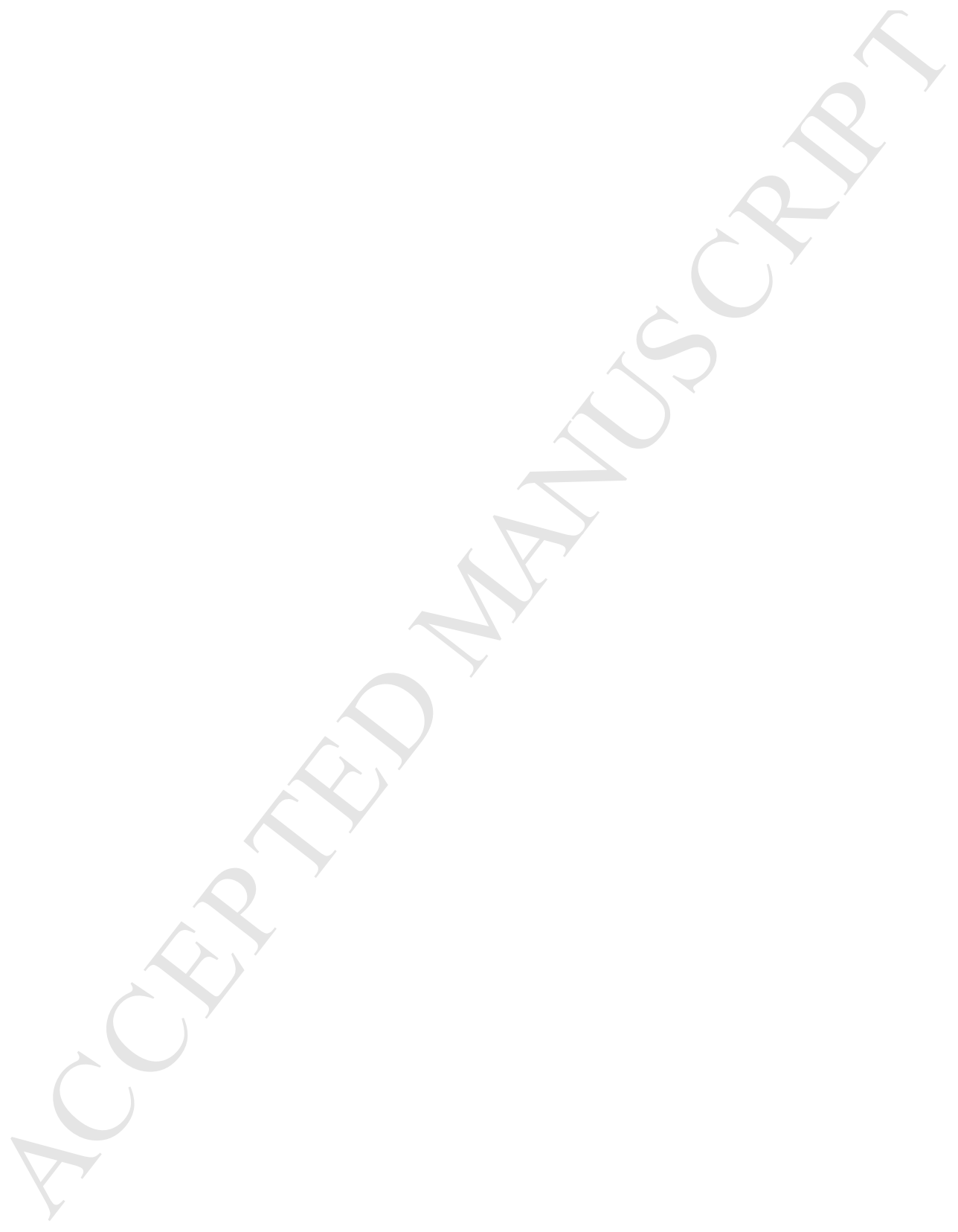




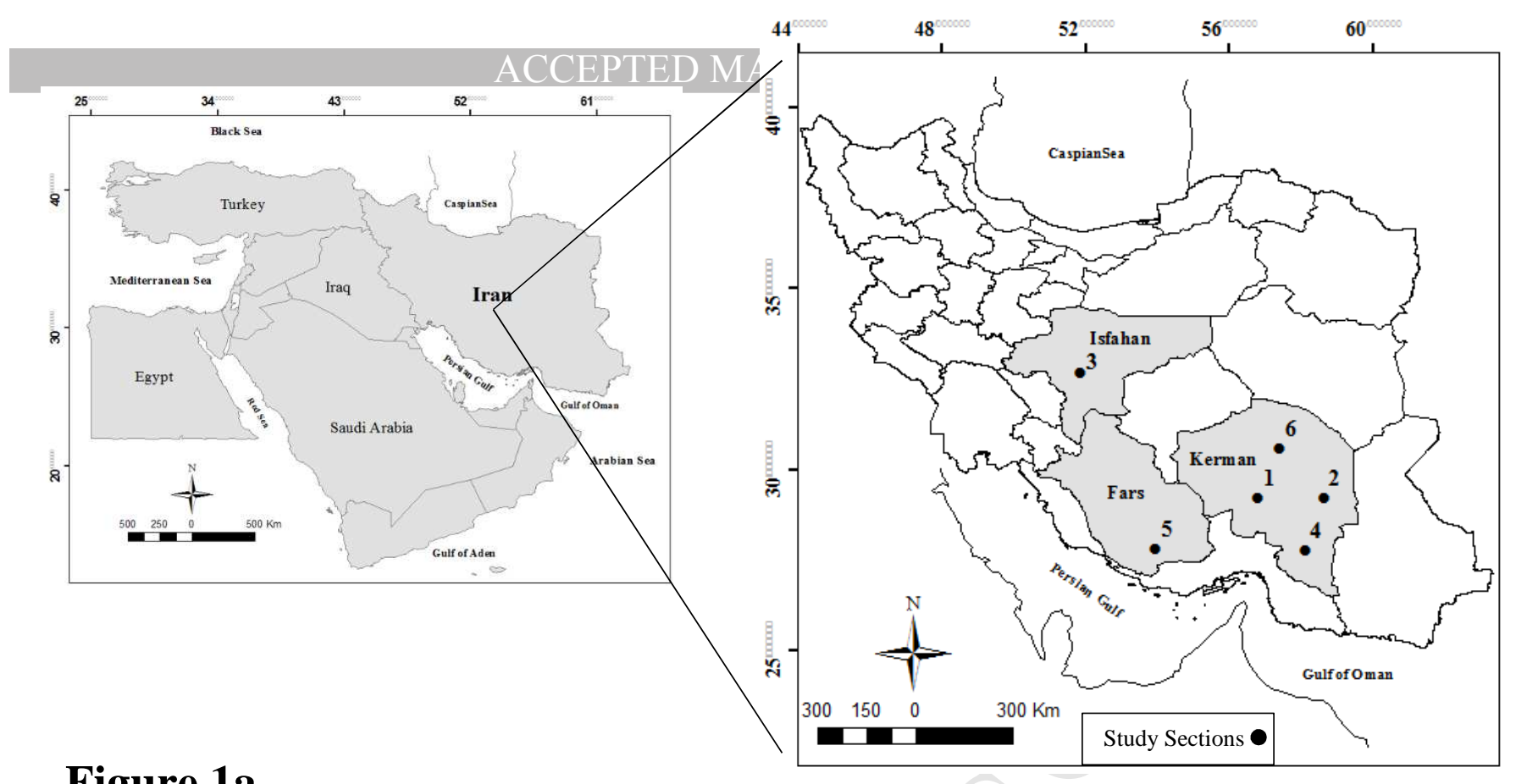

Figure 1a 


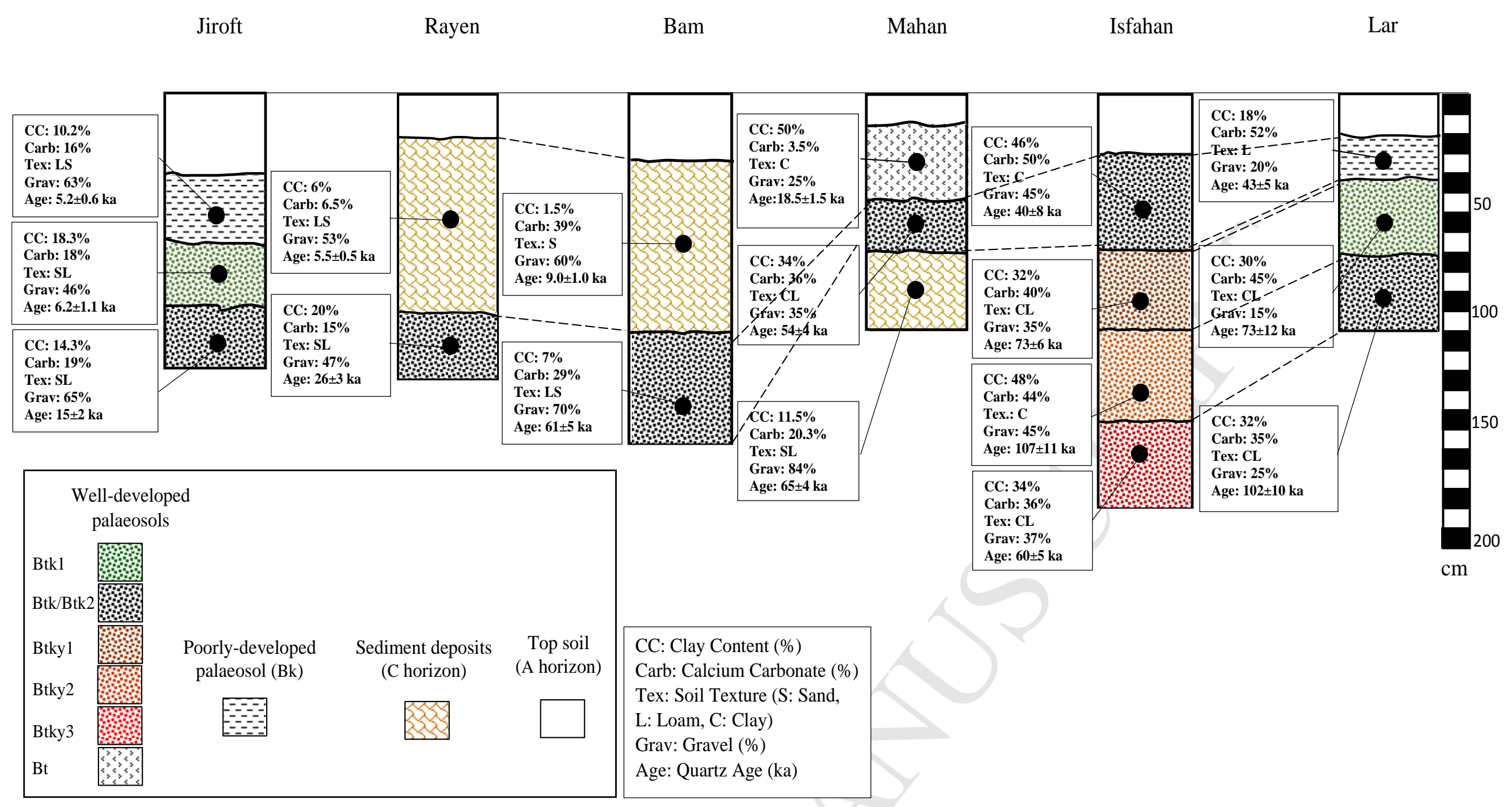

Figure 1b 


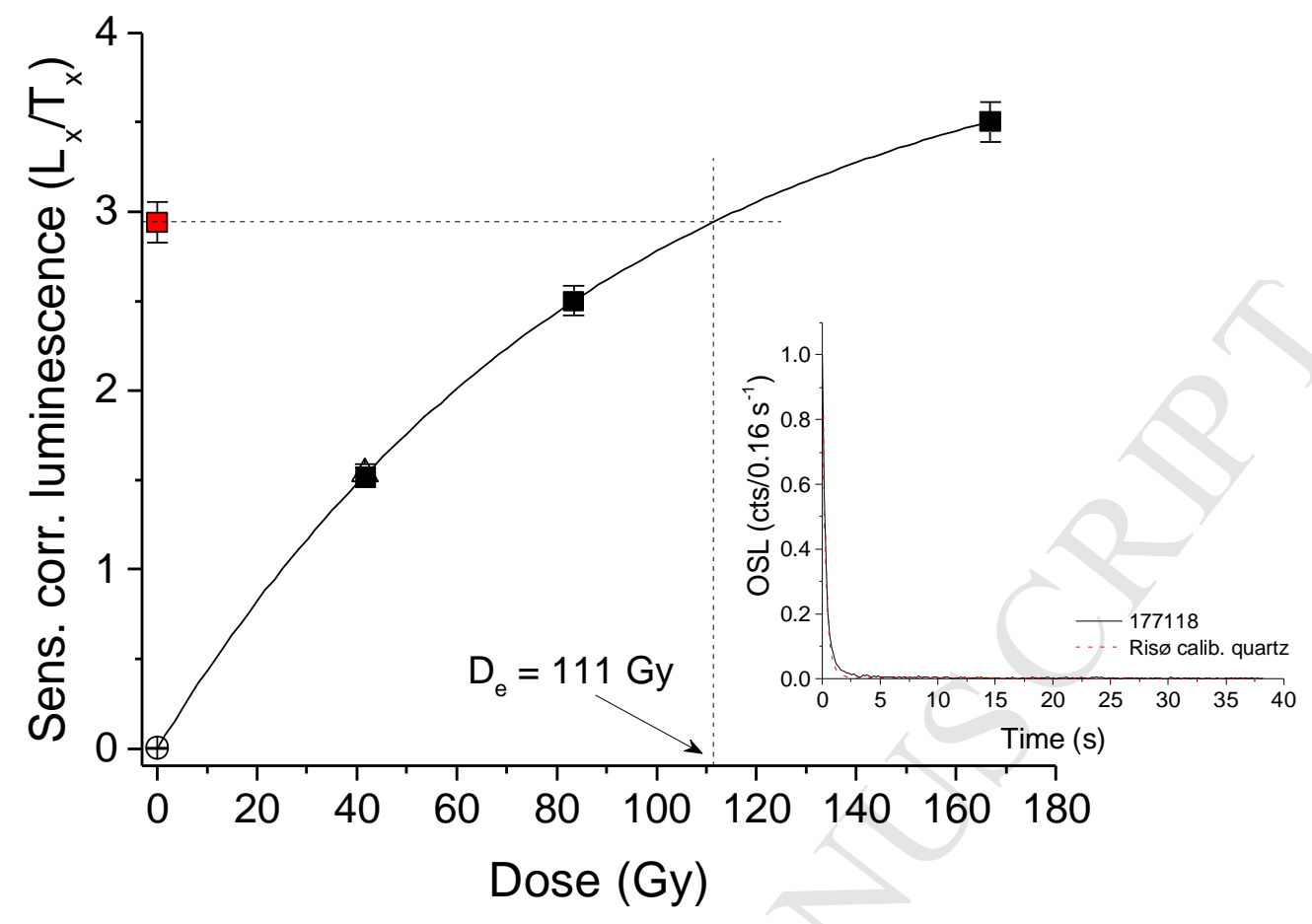

Figure 2a 


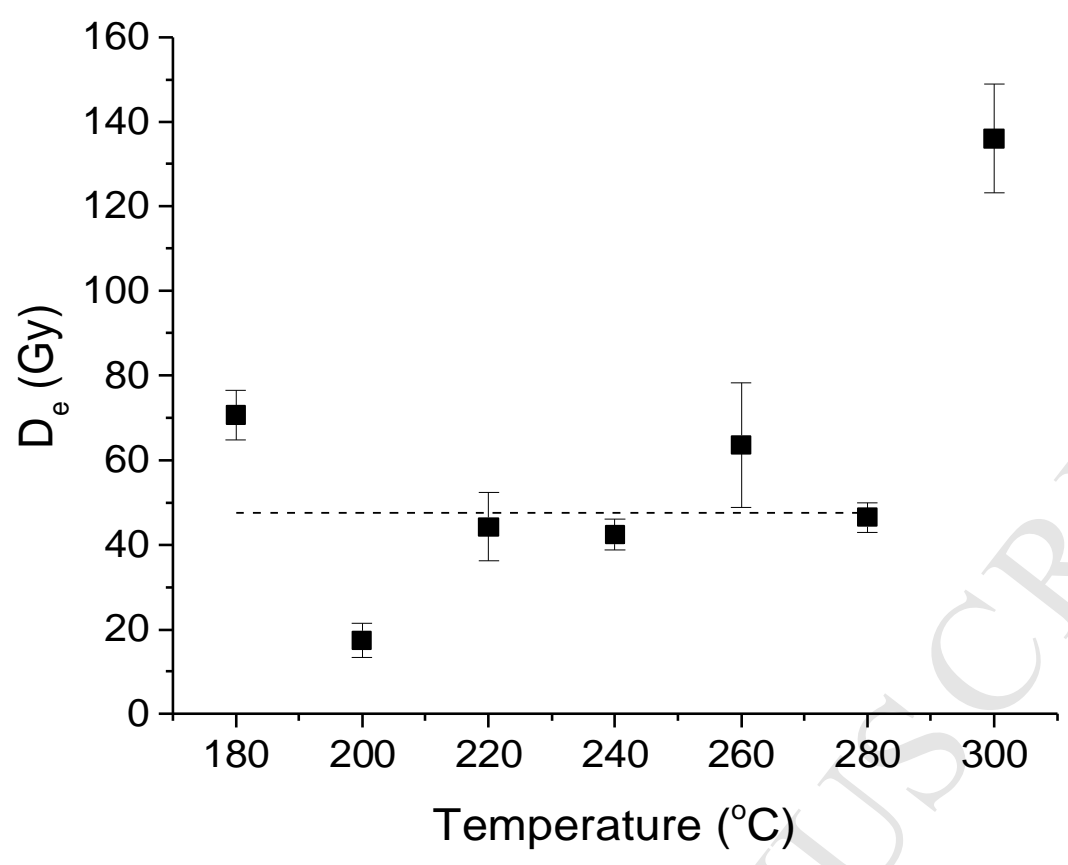

Figure 2b 


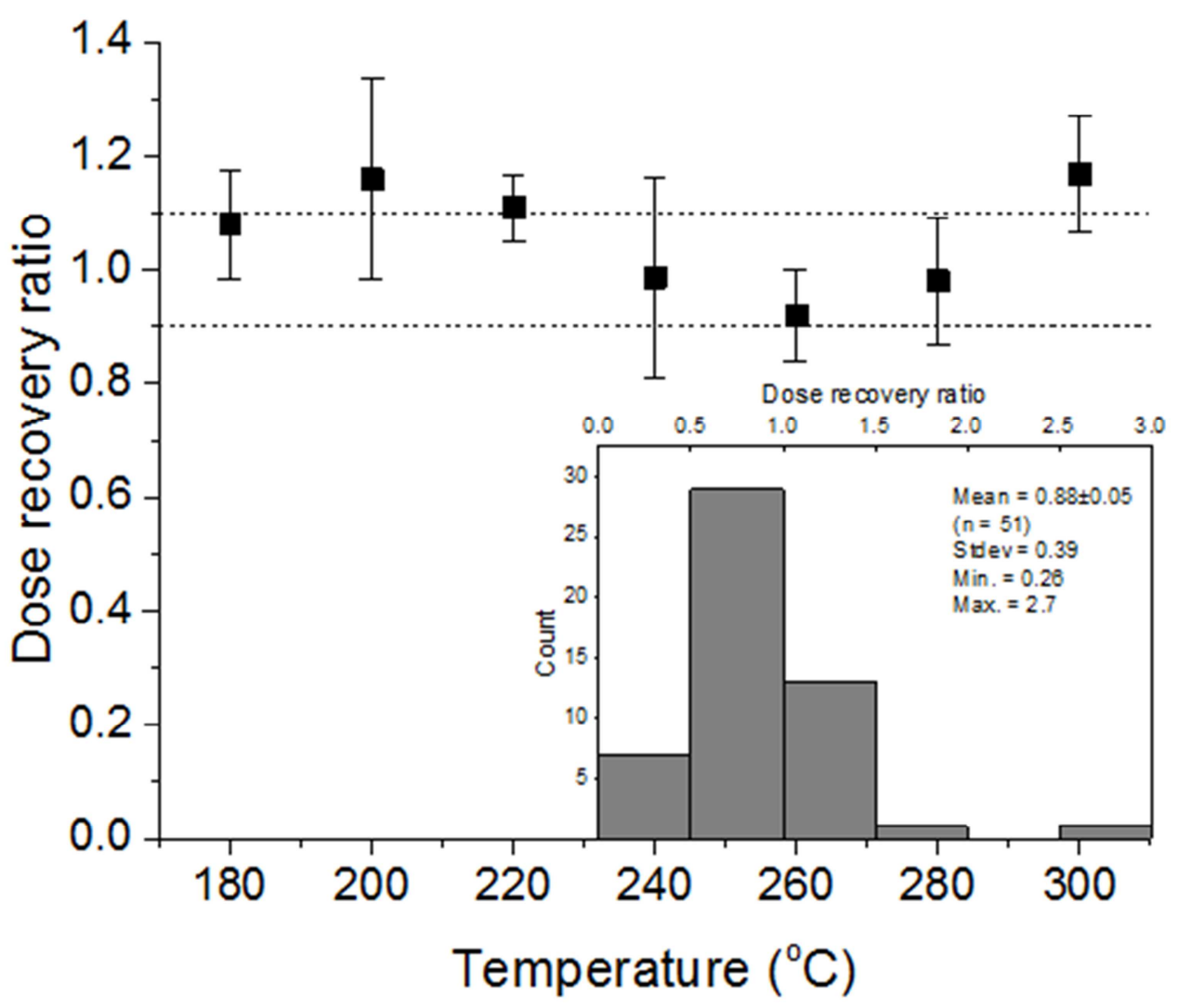

Figure 2c) 


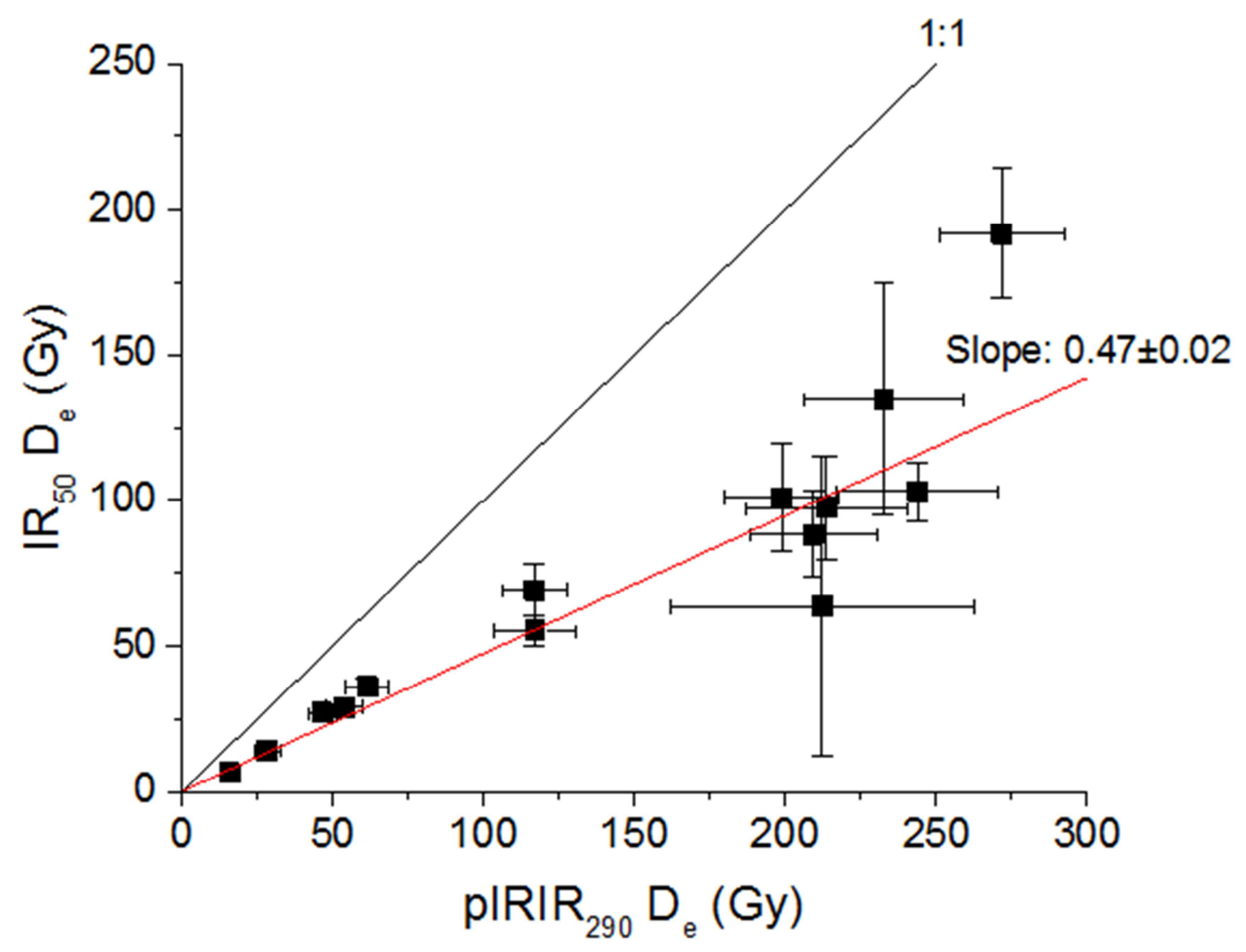

Figure 3a) 


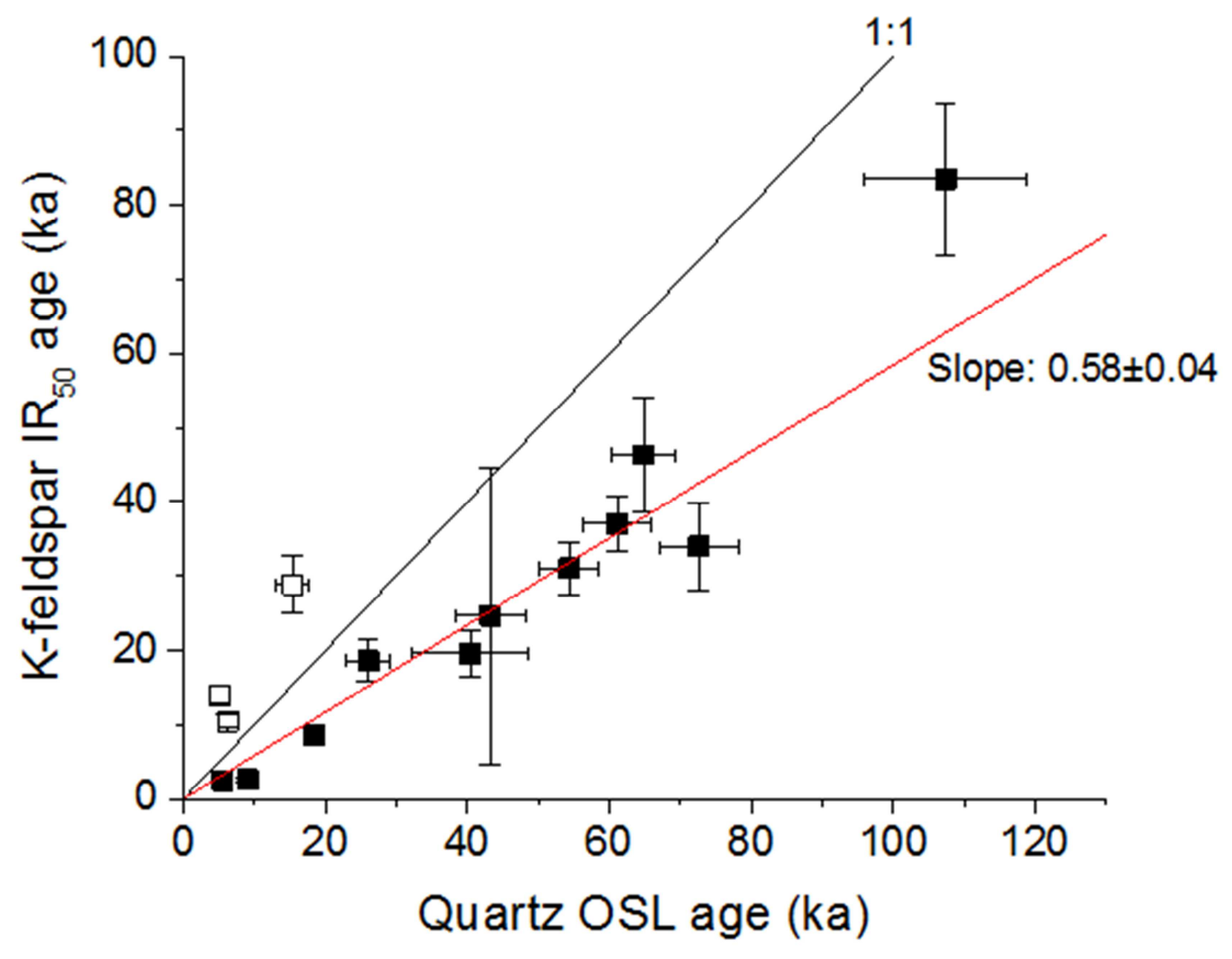

Figure 3b) 


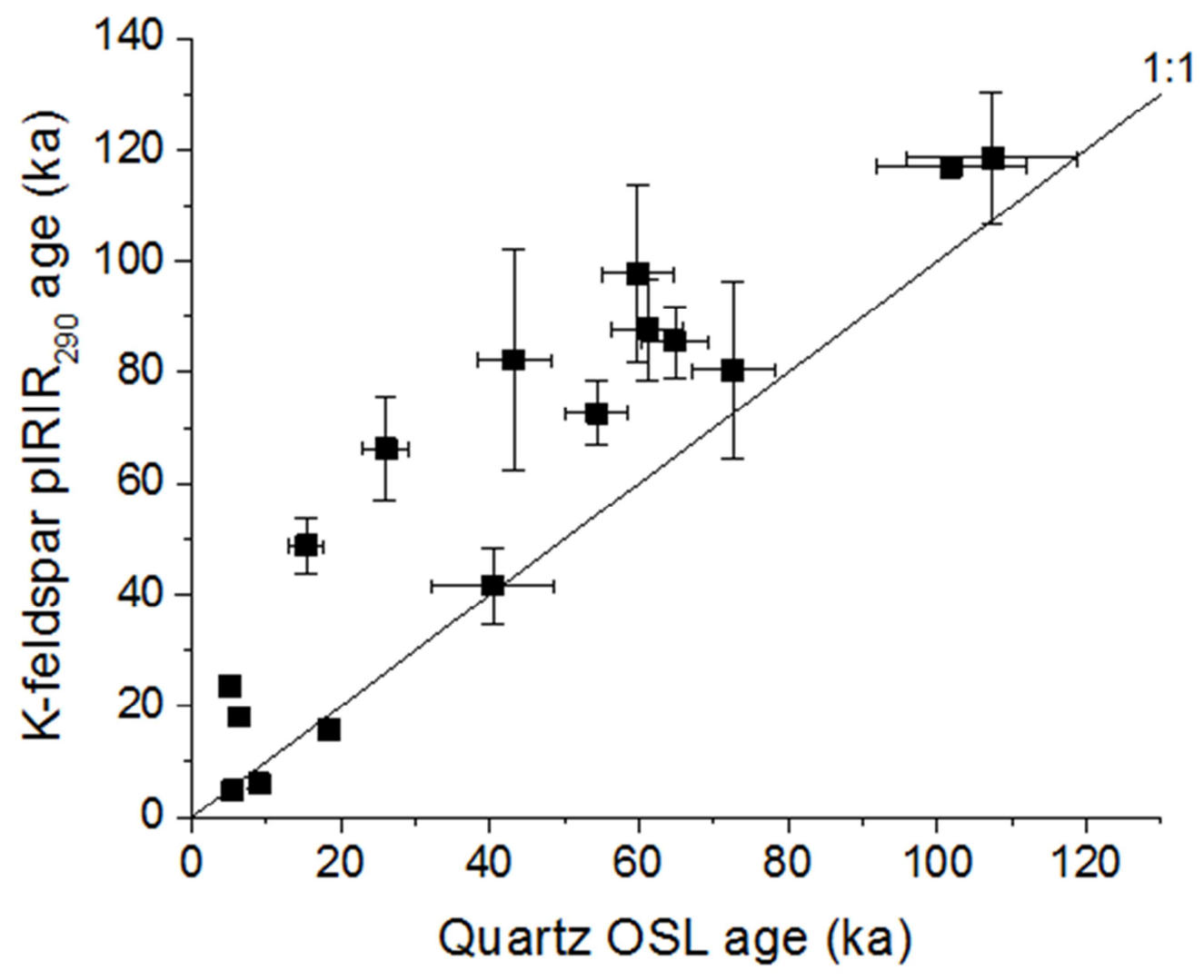

Figure 3c) 


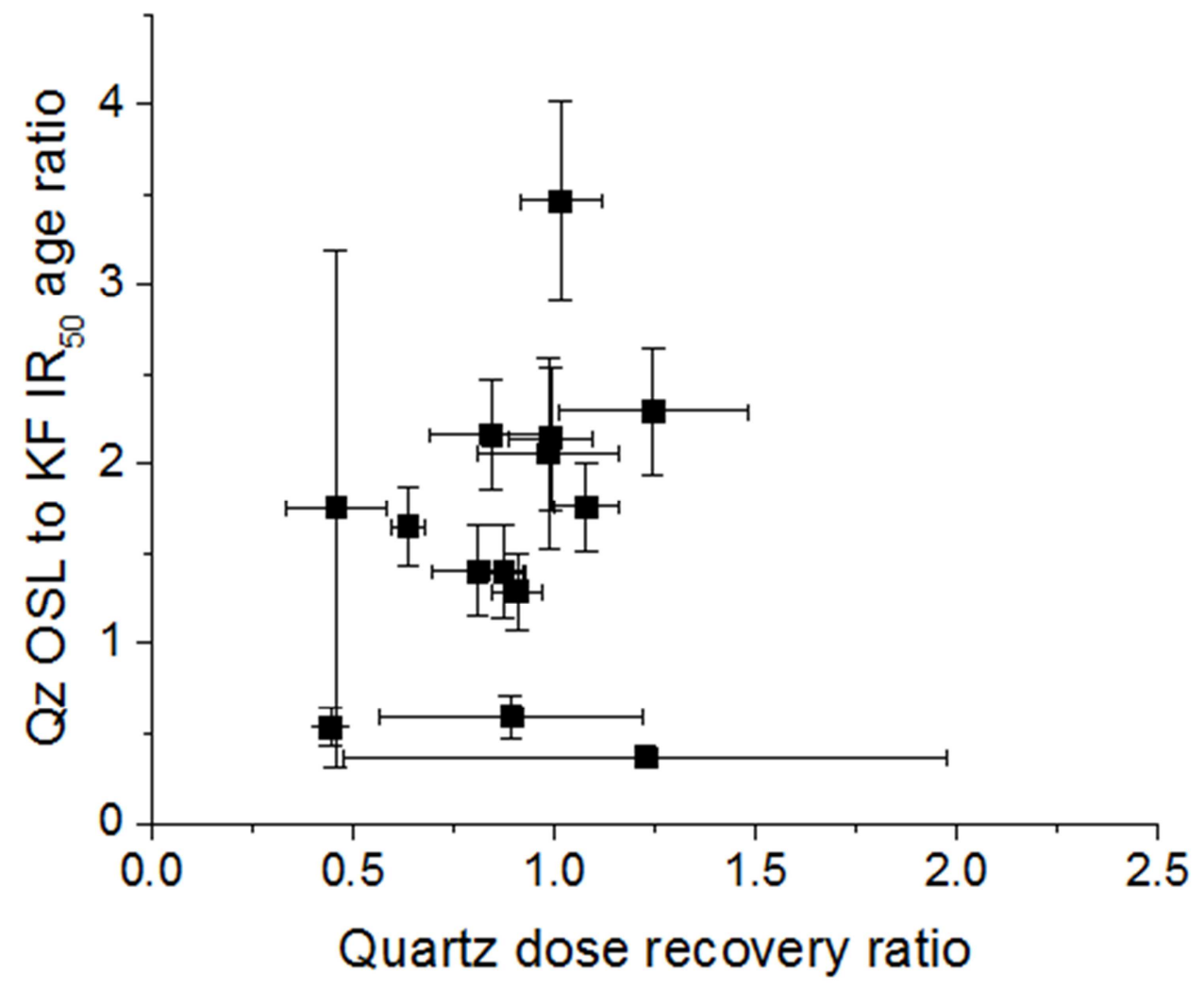

Figure 3d) 


\section{Table 1}

Sampling locations and pedological description of sections

\begin{tabular}{|c|c|c|c|c|c|c|c|c|}
\hline Section & Longitude (E) & Latitude (N) & $\begin{array}{l}\text { Altitud } \\
(\mathrm{m})\end{array}$ & $\begin{array}{l}\text { Mean annual } \\
\text { precipitation } \\
(\mathrm{mm})\end{array}$ & $\begin{array}{l}\text { Mean annual } \\
\text { temperature } \\
(\mathrm{mm})\end{array}$ & Landform & local geology & $\begin{array}{l}\text { Sediment origin } \\
\text { geology }\end{array}$ \\
\hline Rayen & $57^{\circ} 39^{\prime} 21^{\prime \prime}$ & $29^{\circ} 27^{\prime} 25^{\prime \prime}$ & 2328 & 200 & 14 & Pediment & $\begin{array}{c}\text { Quaternary } \\
\text { older gravel } \\
\text { fan }\end{array}$ & $\begin{array}{l}\text { Middle Eocene } \\
\text { Igneous Rocks and } \\
\text { Eocene marl }\end{array}$ \\
\hline Bam & $57^{\circ} 39^{\prime} 39^{\prime \prime}$ & $29^{\circ} 39^{\prime} 55^{\prime \prime}$ & 2096 & 145 & 15.5 & Pediment & $\begin{array}{c}\text { Upper } \\
\text { Neogene to } \\
\text { Quaternary } \\
\text { conglomerate, } \\
\text { sandstone }\end{array}$ & $\begin{array}{l}\text { Cretaceous marl, } \\
\text { sandstone and } \\
\text { Paleocene to Eocene } \\
\text { gypsiferous marl }\end{array}$ \\
\hline Isfahan & $51^{\circ} 51^{\prime} 21^{\prime \prime}$ & $32^{\circ} 40^{\prime} 64^{\prime \prime}$ & 1598 & 150 & 14.7 & $\begin{array}{l}\text { Alluvial } \\
\text { fan }\end{array}$ & $\begin{array}{l}\text { Oligo- } \\
\text { Miocene } \\
\text { limestone }\end{array}$ & $\begin{array}{l}\text { Cretaceous } \\
\text { limestone }\end{array}$ \\
\hline Jiroft & $57^{\circ} 42^{\prime} 50^{\prime \prime}$ & $28^{\circ} 37^{\prime} 53^{\prime \prime}$ & 660 & 185 & 24.5 & $\begin{array}{l}\text { fluvial } \\
\text { plain }\end{array}$ & $\begin{array}{c}\text { Recent } \\
\text { alluvium, river } \\
\text { terraces } \\
\end{array}$ & $\begin{array}{c}\text { Miocene to Pliocene } \\
\text { marl, limestone and } \\
\text { conglomerate }\end{array}$ \\
\hline Lar & $53^{\circ} 57^{\prime} 19^{\prime \prime}$ & $27^{\circ} 47^{\prime} 23^{\prime \prime}$ & 1071 & 170 & 23.3 & Plateau & $\begin{array}{c}\text { Miocene- } \\
\text { Pliocene } \\
\text { gypseous marl, } \\
\text { calacareous } \\
\text { sandstone } \\
\end{array}$ & $\begin{array}{c}\text { Eocene limestone } \\
\text { and marl }\end{array}$ \\
\hline Mahan & $57^{\circ} 17^{\prime} 23^{\prime \prime}$ & $30^{\circ} 08^{\prime} 38^{\prime \prime}$ & 1912 & & 14.5 & $\begin{array}{l}\text { Alluvial } \\
\text { fan }\end{array}$ & $\begin{array}{l}\text { Quaternary } \\
\text { conglomerate } \\
\text { and older } \\
\text { fanglomerate } \\
\text { deposits }\end{array}$ & $\begin{array}{l}\text { Upprt Cretaceous } \\
\text { limestone and } \\
\text { gypsiferous marl }\end{array}$ \\
\hline
\end{tabular}


Table 2

Summary of sample code, burial depth, radionuclide concentrations, measured water content, quartz OSL and K-feldspar IR 50 and pIRIR 290 equivalent doses. Feldspar dose rates assume a K concentration of $12.5 \pm 0.5 \%$ for K-feldspar (Huntley and Baril, 1997). An absolute error of $4 \%$ is assumed on the water content values.

\begin{tabular}{|c|c|c|c|c|c|c|c|c|c|c|c|c|c|c|c|c|c|c|c|}
\hline section & $\begin{array}{c}\text { Sample } \\
\text { code }\end{array}$ & $\begin{array}{l}\text { Depth } \\
\text { (cm) }\end{array}$ & $\begin{array}{l}\text { Water } \\
\text { content } \\
(\%)\end{array}$ & $\begin{array}{c}\begin{array}{c}226 \mathrm{Ra} \\
\left(\mathrm{Bqkg}^{-1}\right) \pm \mathrm{se}\end{array}\end{array}$ & $\begin{array}{c}{ }^{232} \mathrm{Th} \\
\left(\mathrm{Bqkg}^{-1}\right) \pm \mathrm{se}\end{array}$ & $\begin{array}{c}{ }^{40} \mathrm{~K} \\
\left(\mathrm{Bqkg} \mathrm{g}^{-1}\right) \pm \mathrm{se}\end{array}$ & $\begin{array}{c}\text { Total dose } \\
\quad \text { rate } \\
\left(\mathrm{Gyka-}^{-1}\right) \pm \mathrm{se}\end{array}$ & $\begin{array}{l}\text { Quartz } \\
\text { OSL De } \\
\text { (Gy) } \pm s e\end{array}$ & & $\begin{array}{l}\text { Quartz } \\
\text { OSL age } \\
\text { (ka) } \pm \mathrm{se}\end{array}$ & $\begin{array}{c}\text { K-feldspar } \\
I_{s_{5} D_{e}} \\
\left(\mathrm{~Gy}^{\prime}\right) \pm s e\end{array}$ & $\begin{array}{c}\text { K- } \\
\text { feldspar } \\
\text { IRso age } \\
\text { (ka) } \pm s e\end{array}$ & $\begin{array}{l}\text { K-feldspar } \\
\text { pIRIR } 200 \\
(\mathrm{~Gy}) \pm \mathrm{se}\end{array}$ & $\mathrm{n}$ & $\begin{array}{c}\text { K- } \\
\text { feldspar } \\
\text { pIRIR } 290 \\
\text { age } \\
(\mathrm{ka}) \pm \mathrm{se} \\
\end{array}$ & $\begin{array}{l}\text { Age ratio } \\
\text { IR }_{5 / 1} \mathrm{OSL}\end{array}$ & $\begin{array}{c}\text { Age ratio } \\
\text { pIRIR } 200 / O S L\end{array}$ & $\begin{array}{c}\text { Well } \\
\text { bleached }\end{array}$ & $\begin{array}{c}\text { Probably } \\
\text { well } \\
\text { bleached }\end{array}$ \\
\hline \multirow{2}{*}{ Rayen } & 177107 & 60 & 1 & $37.6 \pm 0.64$ & $54.7 \pm 0.83$ & $966 \pm 19.0$ & $4.79 \pm 0.22$ & $27 \pm 2$ & 18 & $5.5 \pm 0.5$ & $13.9 \pm 1.5$ & $2.4 \pm 0.3$ & $28 \pm 2.85$ & 9 & $4.9 \pm 0.5$ & $0.44 \pm 0.06$ & $0.9 \pm 0.12$ & v & $\checkmark$ \\
\hline & 177108 & 115 & 2 & $49.6 \pm 1.11$ & $70.0 \pm 1.01$ & $815 \pm 20.0$ & $4.71 \pm 0.22$ & $125 \pm 10$ & 17 & $26 \pm 3$ & $105.4 \pm 14$ & $19 \pm 3$ & $375 \pm 49$ & 20 & $66 \pm 9$ & $0.71 \pm 0.13$ & $2.5 \pm 0.45$ & & v \\
\hline \multirow{3}{*}{ Bam } & 177111 & 70 & 1 & $19.5 \pm 0.48$ & $14.7 \pm 0.37$ & $256 \pm 8.0$ & $1.64 \pm 0.07$ & $14.7 \pm 1.5$ & 17 & $9.0 \pm 1.0$ & $6.6 \pm 0.86$ & $2.6 \pm 0.3$ & $15.8 \pm 2.4$ & 17 & $6.1 \pm 1.0$ & $0.29 \pm 0.04$ & $0.68 \pm 0.13$ & $\checkmark$ & v \\
\hline & & & & & & & & & & & & & & & & & & & \\
\hline & 177112 & 150 & 4 & $22.3 \pm 0.45$ & $19.5 \pm 0.40$ & $310 \pm 8.0$ & $1.84 \pm 0.08$ & $112 \pm 7$ & 16 & $61 \pm 5$ & $103 \pm 9.9$ & $37 \pm 4$ & $243.9 \pm 22$ & 11 & $88 \pm 9$ & $0.61 \pm 0.08$ & $1.4 \pm 0.18$ & & $\checkmark$ \\
\hline \multirow{5}{*}{ Isfahan } & 177118 & 50 & 4 & $26.6 \pm 1.00$ & $16.1 \pm 0.7$ & $310 \pm 14.9$ & $1.87 \pm 0.35$ & $76 \pm 6$ & 22 & $40 \pm 8$ & $55 \pm 5$ & $20 \pm 3$ & $117 \pm 11.4$ & 12 & $42 \pm 7$ & $0.5 \pm 0.12$ & $1.03 \pm 0.27$ & $\checkmark$ & v \\
\hline & 177119 & 95 & 1 & $26.2 \pm 0.83$ & $13.3 \pm 0.6$ & $253 \pm 12.0$ & $1.67 \pm 0.08$ & $121 \pm 7$ & 16 & $73 \pm 6$ & $88.3 \pm 14.7$ & $34 \pm 6$ & $209 \pm 40.7$ & 6 & $80 \pm 16$ & $0.47 \pm 0.08$ & $1.1 \pm 0.23$ & v & v \\
\hline & & & & & & & & & & & & & & & & & & & \\
\hline & 177120 & 140 & 2 & $24.1 \pm 0.39$ & $10.1 \pm 0.2$ & $186 \pm 5.0$ & $1.36 \pm 0.06$ & $148 \pm 14$ & 17 & $107 \pm 11$ & $191.7 \pm 22$ & $84 \pm 10$ & $271.9 \pm 24.5$ & 2 & $119 \pm 12$ & $0.8 \pm 0.12$ & $1.1 \pm 0.16$ & $\checkmark$ & $\checkmark$ \\
\hline & 177121 & 160 & 2 & $24.4 \pm 0.30$ & $11.8 \pm 0.2$ & $201 \pm 4.0$ & $1.44 \pm 0.06$ & $86 \pm 6$ & 15 & $60 \pm 5$ & $134.86 \pm 39.7$ & $57 \pm 17$ & $232.6 \pm 37$ & 17 & $98 \pm 16$ & $0.95 \pm 0.3$ & $1.1 \pm 0.16$ & v & v \\
\hline \multirow{3}{*}{ Jiroft } & 177125 & 60 & 4 & $17.3 \pm 0.81$ & $14.0 \pm 0.6$ & $313 \pm 14$ & $1.65 \pm 0.08$ & $8.5 \pm 0.9$ & 16 & $5.2 \pm 0.6$ & $36.1 \pm 2.6$ & $14 \pm 1.2$ & $61.4 \pm 3.9$ & 17 & $24 \pm 1.8$ & $2.7 \pm 0.38$ & $4.6 \pm$ & ? & \\
\hline & 177126 & 85 & 3 & $15.2 \pm 0.25$ & $13.6 \pm 0.2$ & $328 \pm 5$ & $1.65 \pm 0.07$ & $10.3 \pm 1.8$ & 16 & $6.2 \pm 1.1$ & $27 \pm 2.2$ & $10.5 \pm 0.9$ & $46.6 \pm 4$ & 14 & $18 \pm 1.7$ & $1.67 \pm 0.33$ & $2.9 \pm$ & ? & \\
\hline & 177127 & 115 & 1 & $11.9 \pm 0.26$ & $11.3 \pm 0.3$ & $290 \pm 6$ & $1.46 \pm 0.06$ & $22 \pm 3$ & 24 & $15 \pm 2$ & $69.8 \pm 8.7$ & $29 \pm 4$ & $\begin{array}{c}116.8 \pm \\
10.6\end{array}$ & 18 & $49 \pm 5$ & $1.9 \pm 0.37$ & $3.3 \pm$ & ? & \\
\hline \multirow{3}{*}{ Lar } & 177129 & 30 & 8 & $53.9 \pm 0.64$ & $9.09 \pm 0.3$ & $138 \pm 6$ & $1.64 \pm 0.08$ & $71 \pm 7$ & 20 & $43 \pm 5$ & $63.59 \pm 51.5$ & $24.6 \pm 20$ & $212 \pm 50.2$ & 4 & $82 \pm 20$ & $0.57 \pm 0.47$ & $1.9 \pm 0.51$ & & v \\
\hline & 177130 & 60 & & $32.3 \pm 0.51$ & $5.5 \pm 0.4$ & $89 \pm 4$ & $1.07 \pm 0.05$ & $79 \pm 13$ & 9 & $73 \pm 12$ & - & - & - & 0 & - & - & - & & \\
\hline & 177128 & 95 & & $35.02 \pm 0.61$ & $6.18 \pm 0.35$ & $99 \pm 6$ & $1.2 \pm 0.05$ & $122 \pm 10$ & 14 & $102 \pm 10$ & & & 249.14 & 1 & 117 & - & $1.15 \pm 0.11$ & & \\
\hline \multirow{3}{*}{ Mahan } & 177131 & & & $26.4 \pm 0.83$ & $24.6 \pm 0.7$ & $426 \pm 14$ & $2.47 \pm 0.11$ & $46 \pm 3$ & 20 & $18.5 \pm 1.5$ & $29 \pm 3.2$ & $8.5 \pm 1.0$ & $53.9 \pm 3.4$ & 15 & $\begin{array}{c}15.8 \pm \\
1.2\end{array}$ & $0.46 \pm 0.06$ & $0.86 \pm 0.09$ & $\checkmark$ & $\checkmark$ \\
\hline & 177132 & 60 & 2 & $21.9 \pm 0.51$ & $18.3 \pm 0.5$ & $281 \pm 9$ & $1.8 \pm 0.08$ & $98 \pm 6$ & 18 & $54 \pm 4$ & $84.6 \pm 9.5$ & $31 \pm 4$ & $198.7 \pm 13$ & 13 & $73 \pm 6$ & $0.57 \pm 0.08$ & $1.34 \pm 0.15$ & & $\checkmark$ \\
\hline & 177133 & 90 & 1 & $18.2 \pm 0.52$ & $15.3 \pm 0.5$ & $241 \pm 8$ & $1.56 \pm 0.07$ & $101 \pm 5$ & 21 & $65 \pm 4$ & $115.6 \pm 18.7$ & $46 \pm 8$ & $213 \pm 13.2$ & 11 & $86 \pm 6$ & $0.71 \pm 0.13$ & $1.33 \pm 0.13$ & & $\sqrt{ }$ \\
\hline
\end{tabular}




\section{Table 3}

Quartz OSL, feldspar $\mathrm{IR}_{50}$ and feldspar pIRIR 290 apparent residual doses in modern analogue samples

\begin{tabular}{lllll}
\hline Sample & Type & Quartz $(\mathrm{Gy})$ & $\mathrm{IR}_{50}(\mathrm{~Gy})$ & pIRIR $_{290}(\mathrm{~Gy})$ \\
\hline Rayen & Alluvial & $1.64 \pm 0.3$ & $0.7 \pm 0.2$ & $4.7 \pm 1.9$ \\
Bam & Alluvial & $0.11 \pm 0.02$ & $0.4 \pm 0.2$ & $1.9 \pm 0.5$ \\
Jiroft & Fluvial & $1.2 \pm 1.01$ & $1.4 \pm 0.2$ & $2.4 \pm 0.5$ \\
Lar & Alluvial & $0.11 \pm 0.02$ & $0.51 \pm 0.15$ & $2.8 \pm 0.47$ \\
Mahan & Alluvial & $0.1 \pm 0.01$ & $2.3 \pm 1.9$ & $3.5 \pm 1.02$ \\
\hline
\end{tabular}




\section{ACCEPTED MANUSCRIPT}

\section{Supplementary materials}

\section{Fig S1}

The photo shows the typical topography of our sampling sites
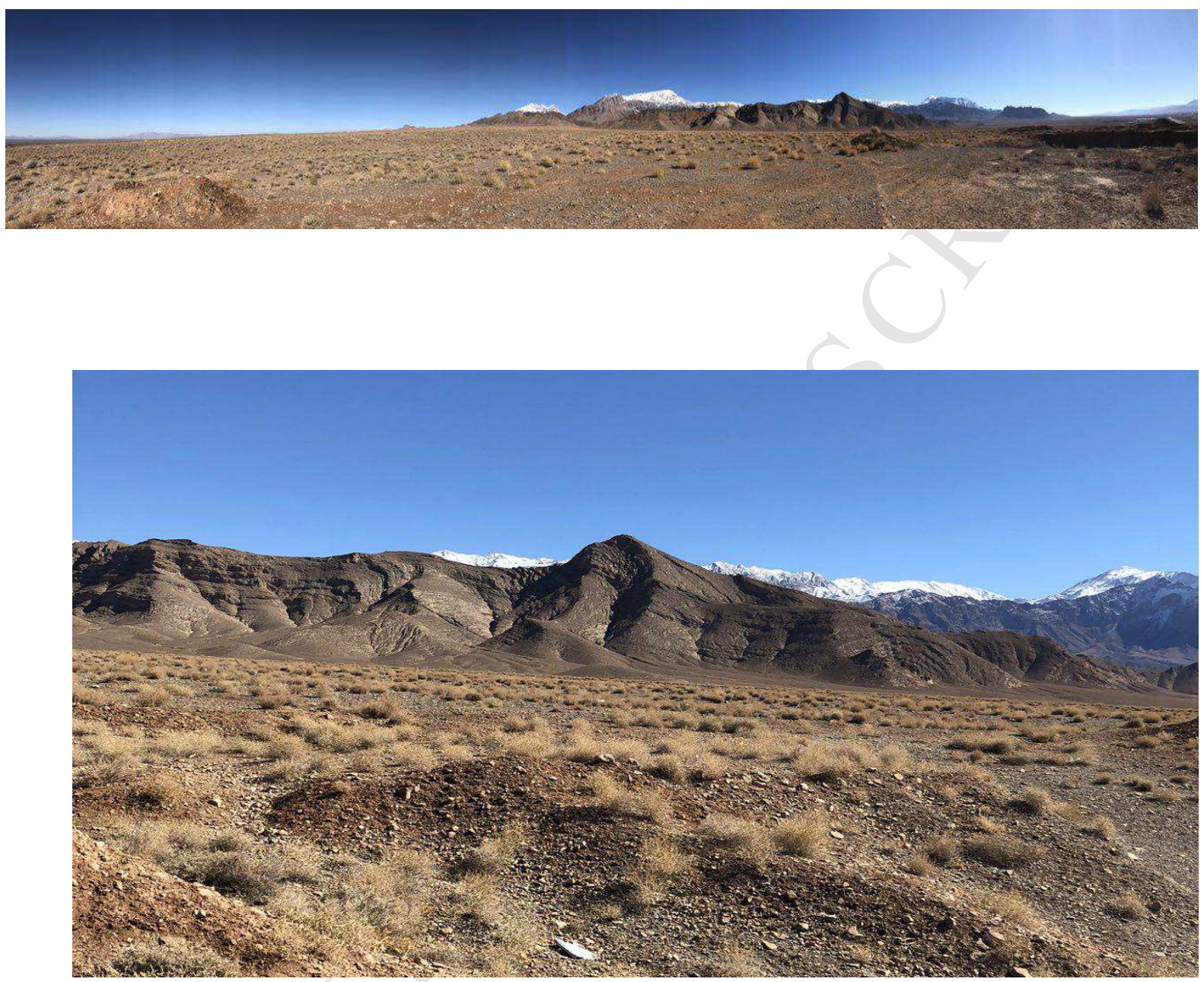


\section{Table S1}

Outline of the SAR OSL and post-IR IRSL protocol (Murray and Wintle, 2003; Buylaert et al. 2012)

\begin{tabular}{llcll}
\hline step & Quartz & Observed & Treatment & Observed \\
\cline { 2 - 5 } & Treatment & Dose & \\
\hline 1 & Dose & Preheat $\left(320^{\circ} \mathrm{C}\right.$ for $\left.60 \mathrm{~s}\right)$ & $\mathrm{L}_{\mathrm{x}}, \mathrm{IR}_{50}$ \\
2 & Preheat $\left(240^{\circ} \mathrm{C}\right.$ for $\left.10 \mathrm{~s}\right)$ & Infrared stimulation $\left(50^{\circ} \mathrm{C}\right.$ for $\left.100 \mathrm{~s}\right)$ & $\mathrm{L}_{\mathrm{x}}, \mathrm{pIRIR}_{290}$ \\
3 & Blue stimulation $\left(125^{\circ} \mathrm{C}\right.$ for $\left.40 \mathrm{~s}\right)$ & $\mathrm{L}_{\mathrm{x}}$ & Infrared stimulation $\left(290^{\circ} \mathrm{C}\right.$ for $\left.100 \mathrm{~s}\right)$ & \\
4 & - & & Test dose & $\mathrm{T}_{\mathrm{x}}, \mathrm{IR}_{50}$ \\
5 & Test dose & & Preheat $\left(320^{\circ} \mathrm{C}\right.$ for $\left.60 \mathrm{~s}\right)$ & $\mathrm{T}_{\mathrm{x}}, \mathrm{pIRIR}_{290}$ \\
6 & Cut heat $\left(290^{\circ} \mathrm{C}\right.$ for $\left.0 \mathrm{~s}\right)$ & $\mathrm{T}_{\mathrm{x}}$ & Infrared stimulation $\left(50^{\circ} \mathrm{C}\right.$ for $\left.100 \mathrm{~s}\right)$ & \\
7 & Blue stimulation $\left(125^{\circ} \mathrm{C}\right.$ for $\left.40 \mathrm{~s}\right)$ & & Infrared stimulation $\left(290^{\circ} \mathrm{C}\right.$ for $\left.100 \mathrm{~s}\right)$ & \\
8 & - & & Infrared stimulation $\left(325^{\circ} \mathrm{C}\right.$ for $\left.100 \mathrm{~s}\right)$ & \\
9 & Blue stimulation $\left(280^{\circ} \mathrm{C}\right.$ for $\left.40 \mathrm{~s}\right)$ & & Return to 1 & \\
10 & Return to 1 & & & \\
\hline
\end{tabular}

